\title{
Imaging of Bing-Neel syndrome
}

\section{Figure Brain MRI revealing a T2 prolongation (A: coronal FLAIR, arrow) in the right parieto-occipital periventricular white matter with patchy enhancement (B: post-gadolinium coronal T1, arrow)}
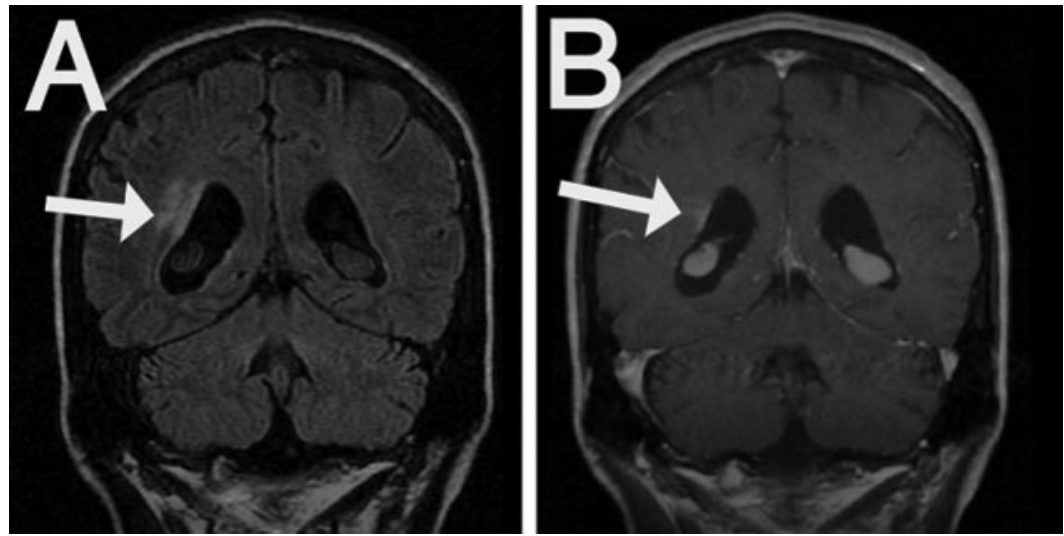

A 64-year-old man with IgM kappa restricted Waldenstrom macroglobulinemia (WM) presented with right frontal headache and transient expressive aphasia. MRI demonstrated regions of enhancement within periventricular white matter with associated FLAIR hyperintensity and no restricted diffusion (figure). CSF analysis showed leukocytes 2 cells $/ \mathrm{mm}^{3}$ (71\% lymphocytes), erythrocytes 73 cells $/ \mathrm{mm}^{3}$, elevated protein of $436.4 \mathrm{mg} / \mathrm{dL}$, glucose of $48 \mathrm{mg} / \mathrm{dL}$, and an M-spike of $34.5 \mathrm{mg} / \mathrm{dL}$ (IgM kappa restricted). CSF cytology showed a population of lymphoplasmacytoid cells and occasional plasma cells. This constellation of findings is suggestive of CNS involvement of WM (Bing-Neel syndrome) and biopsy was not performed. The patient is presently undergoing treatment with a CNS penetrating chemotherapy agent (temozolomide). Neurologic symptoms in patients with WM should raise suspicion of Bing-Neel syndrome, a rare complication of WM characterized by lymphoplasmacytoid infiltration of the brain parenchyma and IgM deposition in the CNS. ${ }^{1}$ In patients with WM and neurologic presentation, CSF analysis and, if inconclusive, biopsy should be considered to rule out alternative neoplastic or infectious processes.

\section{J. Drappatz, MD, S. Akar, D.C. Fisher, MD, M.A. Samuels, MD, and S. Kesari, MD, PhD, Boston, MA} Disclosure: The authors report no conflicts of interest.

Address correspondence and reprint requests to Dr. Santosh Kesari, Brigham and Women's Hospital, Center for Neuro-Oncology, DanaFarber Cancer Institute, SW460, 44 Binney Street, Boston, MA 02115; skesari@partners.org

1. Garderet L, Baudel JL, Cervera P, et al. “Indolent” Waldenstrom's macroglobulinemia and a cerebrospinal fluid protein level of 16 g/L. Eur J Haematol 2006;77:80-82. 


\section{Neurology}

Imaging of Bing-Neel syndrome

J. Drappatz, S. Akar, D. C. Fisher, et al.

Neurology 2008;70;1364

DOI 10.1212/01.wnl.0000309212.22661.84

This information is current as of April 14, 2008

\section{Updated Information \&} Services

\section{References}

Subspecialty Collections

Permissions \& Licensing

Reprints including high resolution figures, can be found at: http://n.neurology.org/content/70/16/1364.full

This article cites 1 articles, 0 of which you can access for free at: http://n.neurology.org/content/70/16/1364.full\#ref-list-1

This article, along with others on similar topics, appears in the following collection(s):

Metastatic tumor

http://n.neurology.org/cgi/collection/metastatic_tumor MRI

http://n.neurology.org/cgi/collection/mri

Information about reproducing this article in parts (figures,tables) or in its entirety can be found online at:

http://www.neurology.org/about/about_the_journal\#permissions

Information about ordering reprints can be found online:

http://n.neurology.org/subscribers/advertise

Neurology ${ }^{\circledR}$ is the official journal of the American Academy of Neurology. Published continuously since 1951, it is now a weekly with 48 issues per year. Copyright . All rights reserved. Print ISSN: 0028-3878. Online ISSN: 1526-632X.

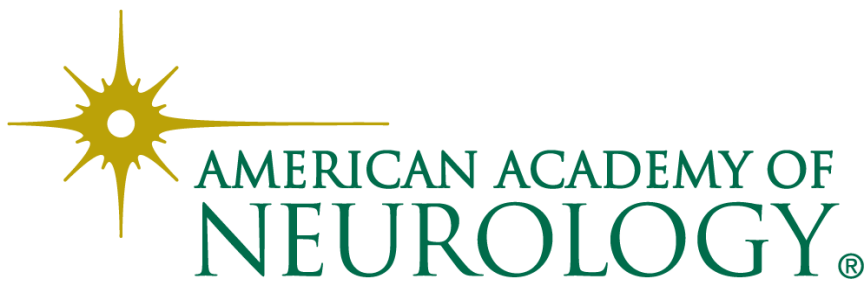

